\title{
Application of species distribution models and conservation planning software to the design of a reserve network for the riverine fishes of northeastern Mesoamerica
}

PETER C. ESSELMAN* AND J. D. ALLAN ${ }^{+}$

*Department of Fisheries and Wildlife, Michigan State University, MI, U.S.A.

${ }^{+}$School of Natural Resources and Environment, University of Michigan, Ann Arbor, MI, U.S.A.

\section{SUMMARY}

1. Protected area networks for river ecosystems must account for the highly connected nature of river habitats and the fact that conditions in distant locations can influence downstream habitats and biota. We used Marxan conservation planning software to address the unique constraints of reserve design in river ecosystems and structure a reserve network to overcome key challenges to freshwater conservation.

2. The range limits of 63 fish species in Mesoamerica were predicted and used in Marxan to design a network of conservation focal areas that encompasses $15 \%$ of the range of each species in areas with low risk of environmental degradation. Upstream risk intensity was estimated by propagating landscape-based sources of stress downstream along the direction of flow in GIS. We constrained Marxan solutions to account for basin divides, and we defined critical management zones to include important habitats that contribute to species persistence and mitigate threats.

3. The proposed reserve network encompassed $11 \%$ of the study area, half of which was contained within existing protected areas. Our exercise also identified important gaps in protection. Because terrestrial-based environmental risks were propagated through the river network and considered in the solution, focal areas were constrained to catchments with low levels of upstream human activity. Addition of critical management zones riparian buffers and fish migration corridors - expanded the network area by one-fifth. 4. Our application of Marxan allowed longitudinal connectivity and topographic barriers to species movement to be considered. Adding critical management zones expanded the size of the reserve network, but is crucial to the network's conservation efficacy. We call for an evaluation of the added management capacity needed to conserve critical management zones and suggest ways to further improve the reserve design process.

Keywords: Marxan, migratory fish, protected areas, species distribution modelling, tropics

\section{Introduction}

Habitats in rivers are influenced by conditions in the entire upstream drainage network (Hynes, 1975;

Correspondence: Peter C. Esselman, Department of Fisheries and Wildlife, Michigan State University, 13 Natural Resources Building, East Lansing, MI 48824-1222, U.S.A.

E-mail: pce@msu.edu

(c) 2010 Blackwell Publishing Ltd
Stoms et al., 2005; Meyer et al., 2007). Riverine biotic assemblages, in turn, are strongly associated with local abiotic factors that are constrained by landscape variables at the scales of the valley segment or watershed (Frissell et al., 1986; Townsend, 1996; Poff, 1997) and are closely linked to upstream-downstream and river-floodplain connectivity (Vannote et al., 1980; Pringle, 1997; Ward \& Wiens, 2001). Owing to this high degree of connectivity, conservation of a 


\section{P. C. Esselman and J. D. Allan}

feature in a river reach may involve interventions to mitigate stressors in geographically distant sites upstream or downstream of the feature of interest (Lake, 1980; Skelton et al., 1995; Pringle, 1997; Moyle \& Randall, 1998). This contrasts with place-based interventions in terrestrial and marine environments where appropriate reserves can protect biodiversity and exclude threats (Possingham et al., 2006). While fundamental differences exist between place-based conservation strategies in terrestrial, marine and freshwater environments, river conservation efforts stand to benefit from the tools developed and lessons learned in systematic conservation planning (sensu Margules \& Pressey, 2000) in terrestrial and marine contexts.

Protected area networks are a key strategy for biodiversity conservation. The design of protected area portfolios is often aided by software that helps identify reserve networks that efficiently protect representative biodiversity (Sarkar et al., 2006). This software generates solutions that satisfy the many criteria that should be considered in protected area planning (see review by Ardron, Possingham \& Klein, 2008). While various authors have explored the concept of freshwater-protected areas (Saunders, Meeuwig \& Vincent, 2002; Linke et al., 2007; Nel et al., 2007; Moilanen, Leathwick \& Elith, 2008; Roux et al., 2008), the highly dynamic and interconnected nature of freshwater ecosystems creates unique challenges to their protection through management of secured land parcels. In a recent exploration of the potential of protected areas for freshwater ecosystems, Abell, Allan \& Lehner (2007) argued that traditional concepts of protected areas do not translate well to fresh waters. Instead of forcing fresh waters 'into the terrestrial mold', they proposed a three-part vocabulary to describe management units that better capture the complexity of using place-based strategies to conserve fresh waters. The central unit of this new vocabulary is a freshwater focal area; the specific location of a freshwater feature needing protection (e.g. a richness hotspot, a critical habitat for spawning). Focal areas are complemented with critical management zones - places that are fundamentally important to maintain the functionality of the focal areas (e.g. a migration corridor for fishes). Finally, a catchment management zone is the entire catchment of a focal area or critical management zone where integrated catchment management principles should be applied (e.g. land use planning to reduce non-point source pollution). In this article, we adopt the conceptual framework of Abell et al. (2007) and some of the tools of systematic conservation planning to propose a network of conservation reserves to protect river fish communities in developing countries of northeastern Mesoamerica.

The ability to undertake systematic conservation planning in developing countries is impeded by a limited understanding of how freshwater ecosystems in these places function, a paucity of baseline research, limited human technical capacity and technology, and limited investment in research and monitoring (Pringle et al., 2000; Wishart et al., 2000). These conditions pose challenges to assembling the basic information needed for conservation planning, particularly data about where biodiversity is located. Of the information sources that can be used to represent spatial patterns in biodiversity, two that are available in many developing countries are: (i) geospatial data about major habitat conditions and (ii) georeferenced species occurrence records of the places where species have been collected. These data can be combined in species distribution models (SDMs) to predict the presence or absence of species in river habitats. In this way, GIS and bioinventory databases can be used to predict species ranges, which can serve as surrogates for biodiversity in conservation planning efforts in information-poor settings.

SDMs generalise the empirical relationships between species occurrences and underlying habitat conditions to predict the probability of species occurrence or abundance within a given area (Guisan \& Zimmermann, 2000). An important strength of SDMs is that they have the potential to use incomplete information, such as historical point occurrence data from only a part of a species' range, to generate spatially comprehensive predictions of the realised niche of a species relative to the environmental variables in the model (Guisan \& Zimmermann, 2000). A strength of using SDMs in conservation planning is that they act as 'filters on habitat from a species-specific viewpoint' (Rondinini et al., 2006), offering potential improvements in the biological realism of conservation plans. Similarly, SDMs with accurate range limits may act as 'filters on historical drivers of biogeography from a species-specific viewpoint', thus addressing one of the main weaknesses of using alternative surrogates for biodiversity such as

(C) 2010 Blackwell Publishing Ltd, Freshwater Biology, 56, 71-88 
abiotic habitat classifications. Habitat classifications can serve as biodiversity surrogates under the assumption that species patterns and ecosystem processes co-vary with patterns in abiotic habitat variation (Higgins et al., 2005). Such classifications follow logically from ecological theory suggesting that abiotic conditions at multiple spatial scales limit the species from the regional species pool that will occupy local habitats (Tonn et al., 1990; Poff, 1997) and have been commonly used in conservation assessments in information-poor settings (e.g. Thieme et al., 2007; Rivers-Moore, Goodman \& Nel, 2010). Ultimately, if the goal is to develop reserve networks for all biodiversity, an approach that integrates biotic and abiotic surrogates may yield the best results (e.g. the coarse-and-fine filter surrogate approach of Roux et al. (2008)). In the absence of an abiotic classification, this article focuses on how species range predictions from SDMs can be used to create a reserve network that will protect representative biodiversity.

Many techniques are available to model species distributions, with different requirements for input data and differences in how they specify empirical relationships between predictor variables and species locations (Elith et al., 2006). In the data-poor settings present in many tropical developing countries, it is important for the method selected to: (i) work with presence-only data on species occurrences, because it is often difficult to infer absences in a consistent manner from datasets collected by different methods or sampling intensities (Graham et al., 2004) and (ii) perform well with few sampling localities. As with the application of conservation planning software in freshwater contexts, it is important for SDMs to be implemented with consideration of the directional and highly connected nature of river ecosystems.

Reserve design programmes use algorithms to determine the minimal set of sites in which conservation features of interest can be adequately represented within a reserve network. As used here, a conservation feature is 'a measureable, spatially definable component of biodiversity that is to be conserved within a reserve network' (Ardron et al., 2008). Conservation features are represented in reserve networks according to representation targets (e.g. $400 \mathrm{~km}$ of occupied river reach; $20 \%$ of range) that are ideally set according to ecological criteria (e.g. viability assessments). The goal of the planning process is to define a reserve network solution that adequately accounts for all relevant conservation features within a network portfolio (Sarkar et al., 2006). Marxan (Ball, Possingham \& Watts, 2009) is a popular and commonly used software for designing efficient conservation area networks. Marxan's simulated annealing algorithm identifies a portfolio of planning units (e.g. catchments) that most efficiently meets predefined targets for protection of one or numerous conservation features, while also meeting the general criteria of reserve design (e.g. comprehensiveness, efficiency, complementarity, etc.; Possingham, Ball \& Andelman, 2000; Ball et al., 2009). In the vocabulary of Abell et al. (2007), Marxan is a suitable method for selecting freshwater focal areas.

We applied Marxan in conjunction with SDMs for 63 freshwater fish species to explore efficient networks of freshwater focal areas that protect the majority of fish species in the watersheds that drain to the coast of Belize. Using these focal areas and applicable concepts from freshwater conservation biology, we recommend critical management zones and catchment management zones that support persistence of specific feature groups within the fish community (migratory species, apex predators and sub-regional endemics). In doing so, we explore (i) how SDMs can be applied in a datalimited freshwater context to enhance conservation planning for biodiversity, (ii) how Marxan can accommodate the unique constraints of reserve network design in flowing water ecosystems and (iii) how an effective reserve network may be structured in a way that responds to the realities of place-based conservation in fresh waters.

\section{Methods}

Study area

Our planning exercise was carried out for the rivers that drain to the coast of Belize, including portions of southern Mexico and northeastern Guatemala. This $45750 \mathrm{~km}^{2}$ area comprises 16 major basins and many small coastal tidal creek basins (Fig. 1). These basins vary in size, traverse a variety of geologies and soil types and drain a diversity of terrestrial land cover types (Lee, Stednick \& Gilbert, 1995; Esselman \& Boles, 2001). Twelve of the 16 major rivers originate in the Maya Mountains (Fig. 1) as high-gradient, low $\mathrm{pH}$ streams draining granite and metamorphic rocks, 


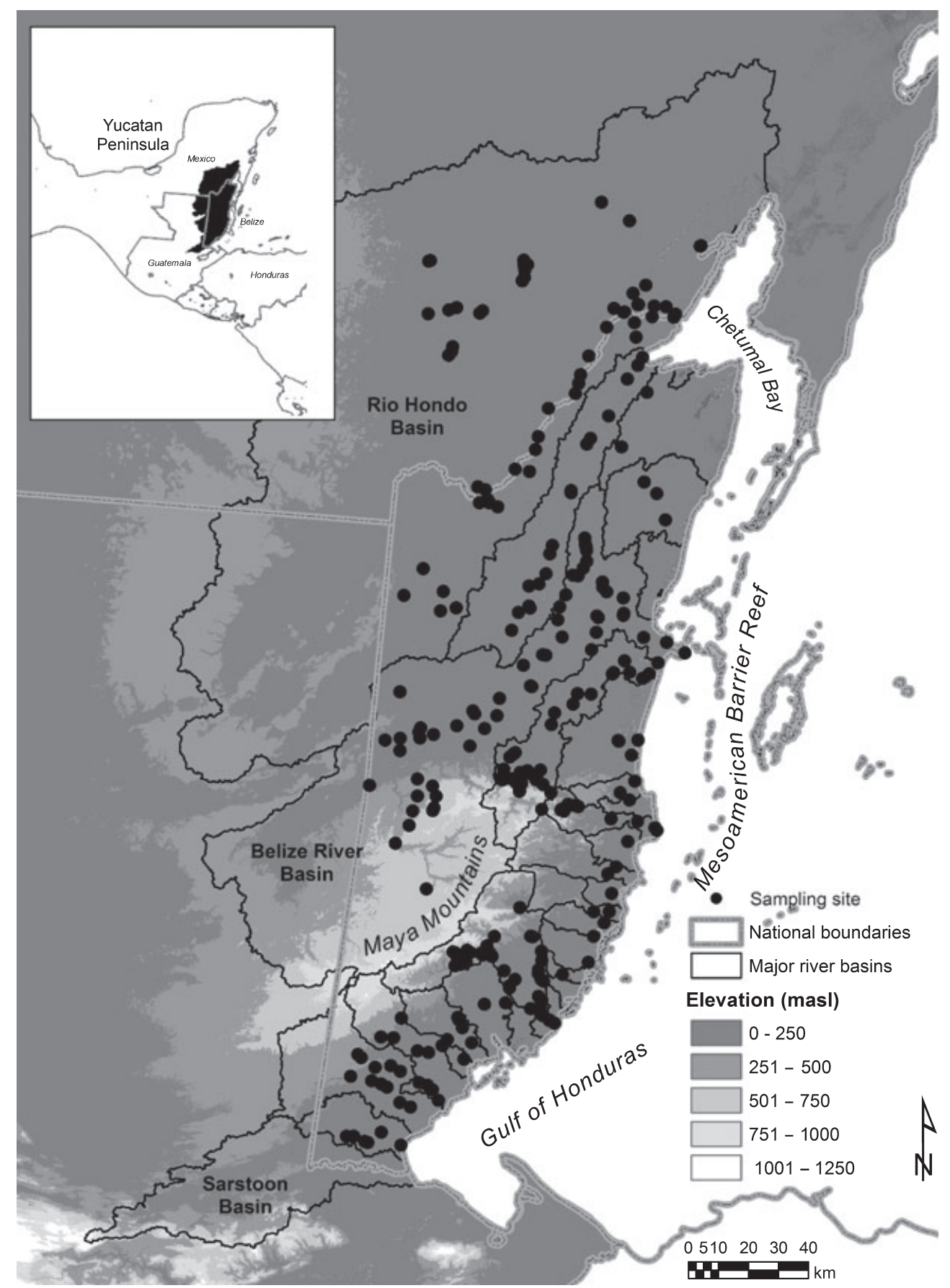

Fig. 1 Study area showing elevation, hydrography and the locations of all sampling sites used for presence-only modelling with Maxent.

after which they traverse a narrow coastal plain and discharge into the shelf lagoon that separates the coast from the Mesoamerican Barrier Reef. The two northernmost rivers in the area ( $\mathrm{N}$ to $\mathrm{S}$; Rio Hondo and New River) originate in karst hills, drain the low-relief limestone platform of the Yucatan Peninsula and discharge into Chetumal Bay. The headwaters of the rivers in the three southernmost basins ( $\mathrm{S}$ to $\mathrm{N}$; Sarstoon, Temash, and Moho Rivers) begin in Guatemala and flow eastward to the Gulf of Honduras. The (c) 2010 Blackwell Publishing Ltd, Freshwater Biology, 56, 71-88 
study area has an abundance of fresh- and brackishwater lagoons and wetlands often associated with riverine habitats (Esselman \& Boles, 2001).

Daily mean temperatures are warm throughout the year, ranging from $16{ }^{\circ} \mathrm{C}$ in winter to $33^{\circ} \mathrm{C}$ in summer (Hartshorn et al., 1984). A strong north-to-south precipitation gradient exists with the northern portion of the study area receiving c. $1000 \mathrm{~mm}$ of rain annually and the southern portion receiving up to $4000 \mathrm{~mm}$ per year (Wilson, 1980). The timing of precipitation is seasonal, with a dry season lasting from December to May and a wet season from June to November. The area is highly prone to hurricanes in the late summer and early fall (Wilson, 1980).

Northern Mesoamerica has been called a 'strong centre of evolution' for fishes, because of its many endemic genera and species (Miller, 1966). The area encompassing the Yucatan Peninsula, Tabasco and part of Chiapas state in Mexico, and the Caribbean slope of Belize, Guatemala and Honduras shares a common biogeographic history and contains a high diversity of poeciliids (34 species, 15 genera) and cichlids (44 species, five genera) (Miller, 1966; Bussing, 1976). A total of 126 fish species have been reported in the study area (Schmitter-Soto \& GamboaPerez, 1996; Greenfield \& Thomerson, 1997; SchmitterSoto, 1998; Esselman, Freeman \& Pringle, 2006).

\section{Species distribution models}

The goal of our modelling process was to use species locality data to model the ranges of all species for which sufficient data were available from landscape predictor variables. We selected a modelling approach called Maxent that requires only species presence data and performs well with low sample sizes (Phillips, Dudík \& Schapire, 2004; Phillips, Anderson \& Schapire, 2006). Inputs to Maxent are raster data layers of environmental attributes important to freshwater fish distributions and georeferenced fish presence locality data. An

Table 1 Environmental variables prepared for entry into Maxent models of fish species distributions. Variables in bold represent those that were selected for entry into the species distribution models after variable reduction with principal components analysis. Eigenvector loadings for the first three axes are listed to the right. The first axis accounted for $22 \%$ of the variance, the second for $14 \%$ and the third for $10 \%$

\begin{tabular}{|c|c|c|c|c|c|c|}
\hline Variable (units) & Min & Max & Mean & Vector 1 & Vector 2 & Vector 3 \\
\hline Average annual air temp in catchment (degrees C) & 20 & 26 & 23 & -0.12 & -0.04 & 0.03 \\
\hline Average annual rainfall in catchment (mm) & 117 & 4070 & 1886 & 0.17 & 0.42 & 0.13 \\
\hline Average catchment elevation (masl) & $<1$ & 1047 & 334 & 0.36 & -0.14 & 0.04 \\
\hline Average catchment slope (percent) & 0 & 36 & 9 & 0.34 & -0.01 & -0.01 \\
\hline Elevation of study reach (masl) & 0 & 1051 & 240 & 0.30 & -0.12 & 0.03 \\
\hline Flow accumulation (pixels) & 0 & 18300373 & 174771 & -0.12 & -0.32 & 0.01 \\
\hline Horizontal land distance to next perennial lake $(\mathrm{km})$ & 0 & 120 & 33 & 0.31 & -0.15 & 0.18 \\
\hline Surface area of nearest lake $\left(\mathrm{km}^{2}\right)$ & 0.52 & 56.78 & 6.13 & 0.07 & 0.08 & -0.07 \\
\hline Distance downstream to sea $(\mathrm{km})$ & 0 & 500 & 161 & 0.18 & -0.30 & 0.07 \\
\hline Upstream distance to furthest basin divide (km) & 0 & 504 & 13 & -0.10 & -0.34 & 0.02 \\
\hline \multicolumn{7}{|l|}{ Catchment geology proportions } \\
\hline Alluvium & 0 & 1 & 0.13 & -0.20 & 0.73 & -0.32 \\
\hline Limestone & 0 & 1 & 0.47 & -0.20 & -0.24 & 0.28 \\
\hline Lavas-pyroclastics-volcanic sediments & 0 & 1 & 0.34 & 0.38 & -0.02 & -0.18 \\
\hline Sedimentary & 0 & 1 & 0.02 & -0.09 & -0.01 & -0.07 \\
\hline Clastic sedimentary & 0 & 1 & 0.03 & -0.02 & 0.25 & 0.43 \\
\hline \multicolumn{7}{|l|}{ Catchment soil proportions } \\
\hline Cambisol-Leptosol-Vertisol & 0 & 1 & 0.06 & -0.01 & 0.23 & 0.49 \\
\hline Fluvisol-Cambisol-Vertisol & 0 & 1 & 0.04 & -0.05 & -0.21 & -0.10 \\
\hline Gleysols & 0 & 1 & 0.02 & -0.05 & -0.07 & -0.02 \\
\hline Gleysols-Fluvisols & 0 & 1 & 0.03 & -0.13 & -0.01 & -0.07 \\
\hline Gleysols-Vertisols & 0 & 1 & 0.03 & -0.10 & -0.04 & -0.03 \\
\hline Gleysols-Vertisols-Fluvisol & 0 & 1 & 0.03 & -0.12 & 0.15 & -0.25 \\
\hline Leptosol & 0 & 1 & 0.02 & -0.02 & 0.17 & 0.36 \\
\hline Leptosol-Cambisol & 0 & 1 & 0.30 & 0.38 & -0.02 & -0.11 \\
\hline Leptosols-vertisols & 0 & 1 & 0.38 & -0.19 & -0.35 & 0.13 \\
\hline Litosol-Cambisol & 0 & 1 & 0.02 & 0.06 & 0.09 & -0.15 \\
\hline
\end{tabular}


76 P. C. Esselman and J. D. Allan

independent variable database was generated (Table 1) and reduced to seven model inputs using principal components analysis. Our fish locality data derived from four ichthyological studies: 111 sites collected in Belize from 1970 to 1980 (Greenfield \& Thomerson, 1997); 63 sites collected in the mid-1990s in Mexico (Schmitter-Soto \& Gamboa-Perez, 1996; Schmitter-Soto, 1998); 21 sites collected in 2000 in Belize (Esselman et al., 2006) and 108 sites from Belize collected in 2006-2008. The final fish database contained 126 species and 303 sample localities. Based on results of Maxent performance studies with low sample sizes (Hernandez et al., 2006), only those species for which five or more data points were available were used to develop SDMs ( $n=63$; Appendix S1).

Maxent species modelling software (v.3.2.1; http:// www.cs.princeton.edu/ schapire/maxent/) was run with the default parameters (Phillips et al., 2006). We used a null model approach to assess model validity by comparing the area under the curve (AUC) of the receiver operating characteristic plot (see Fielding \& Bell, 1997 for details) for each SDM against the upper boundary of a $95 \%$ confidence interval created from the AUCs of 100 null models trained from points drawn randomly from our 303 collection localities (Raes \& ter Steege, 2007). A SDM with an AUC significantly higher than the mean of the null model AUCs was considered valid for our purposes.

The output from Maxent is a probability surface with values ranging from zero to one for all cells in the study area. The continuous probability outputs of all SDMs were classified into binary grids representing species presence and unknown presence by applying a threshold. The minimum training presence value was used as the threshold, which can be interpreted as the probability value under the minimum known suitable habitat condition (Phillips et al., 2006).

\section{MARXAN analysis}

The Marxan simulated annealing algorithm was used to select a portfolio of freshwater focal areas. In each of many iterations, the algorithm identifies a portfolio of planning units that efficiently meets predefined goals for protection of one or numerous conservation features (Game \& Grantham, 2008). The most efficient portfolio is the one that minimises a measure of cost while still meeting conservation goals. Total cost is defined as:

$$
\begin{aligned}
\text { Total Cost } & =\sum \text { Unit Cost }+\sum \text { Species Penalties } \\
& +\sum \text { Boundary Length }
\end{aligned}
$$

where total cost is the objective function to be minimised; unit cost is the cost assigned to each planning unit based on some measure of the intensity of human activity in that unit (see below), species penalties are costs imposed for failing to meet representation goals, and boundary length is a cost determined by the outer boundary length of the portfolio. The boundary length penalty guides Marxan towards solutions that clump planning units, because such configurations have lower outer boundary lengths. Simulated annealing attempts to minimise total portfolio cost by selecting the minimum set of planning units with the lowest total cost needed to meet all biodiversity representation goals.

We implemented Marxan using seven steps that began with the definition of planning units and culminated in a reserve network complete with focal areas and secondary management zones (Fig. 2). The planning units for this study were the 36429 local

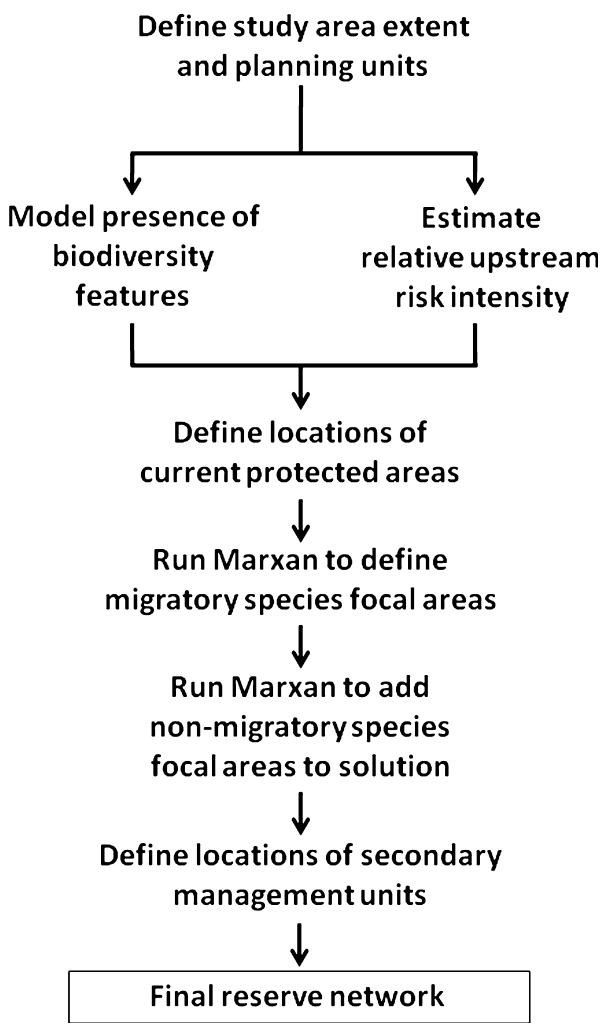

Fig. 2 Seven steps in our implementation of Marxan.

(C) 2010 Blackwell Publishing Ltd, Freshwater Biology, 56, 71-88 
catchments that make up the river basins of our study area. Local catchments are the topographically defined areas that drain laterally to a specific confluence-to-confluence river reach and were derived from a 30-m digital elevation model using Arc Hydro tools (version 9) for ArcGIS 9.2 (Redlands, CA, USA). Marxan requires the input of a boundary file that contains information about connectivity between planning units to assist with aggregation of units in the final solution. We created a boundary file that accounted for basin divides by generating separate boundary files for each basin using the input generator for the Protected Areas Tools for ArcMap 9.2 (v. 2.0; http://www.gispatools.org), then combining them into one file before input into Marxan. Consequently, adjacent catchment units separated by a drainage divide were not counted as connected in the reserve selection procedure.

To define conservation features, we drew on knowledge of the species in our study area and on recent freshwater conservation assessments conducted by stakeholder groups in the study area. Species can be assigned greater importance in the final solution in Marxan by adjusting a species penalty factor (SPF) associated with each biodiversity feature. The SPF adjusts the magnitude of the cost for not meeting the representation target for a given species in the 'species penalties' term of the total cost function. Migratory species, apex predators and regional endemics were given higher SPF values according to their presumed conservation value. At least six migratory species are present in the study area - four amphidromous and two catadromous (Appendix S1). Spawning and down-migration of fishes in the study area are thought to correspond with wet season flood events (Cruz, 1987, 1989; Benstead et al., 1999), and up-migration occurs in mixed-species post-larval migrations in the transition between the wet and dry season (Gilbert \& Kelso, 1971; Winemiller \& Leslie, 1992). These species use both fresh and salt water during their life cycles and thus indicate the integrity of ridge-to-estuary connectivity. The Nature Conservancy in Belize has identified migratory species as important biodiversity feature in recent planning exercises (PCE, personal observation). Apex predators (defined here as species with trophic levels $>4$ according to http://www. fishbase.org) play important roles in the maintenance of aquatic food web structure (Halpern et al., 2005) and were given higher SPF values. Finally, the study area composes a large portion of the ranges of several narrowly distributed endemics whose viabilities depend on their ability to persist there. These species were weighted according to the number of freshwater ecoregions (Abell et al., 2008) that they occupy, with species occupying only one of the 16 ecoregions found in Mesoamerica receiving the highest SPF, and those occupying less than four ecoregions receiving a lower SPF (Appendix S1). Ecoregional presence in this case was established by comparing the range limit descriptions for each species in http:// www.fishbase.org to the freshwater ecoregion map of Abell et al. (2008).

We defined the representation target for each conservation feature as a fixed proportion of the total predicted distribution. We selected a target of $15 \%$ of the range of each species - an arbitrary number selected for purposes of management feasibility and because sufficient ecological information to specify the amount of habitat needed ensure species viability was lacking.

The unit cost term in Marxan's total cost function represents some measure of the cost of including a specific planning unit in the reserve system. In this study, we reasoned that planning units with a higher risk of environmental degradation from human activities were less suitable for conservation and should carry a higher cost of inclusion in the reserve network. Risk of environmental degradation in a riverine context must account for the strong terrestrial-aquatic linkage between a river and its catchment (Hynes, 1975; Stoms et al., 2005; Meyer et al., 2007). We created an environmental risk surface (ERS) and propagated the risk values through the river network along the direction of flow to define the unit cost for each catchment unit (following Schill \& Raber, 2008).

An ERS is a modelled composite raster surface that is created in GIS to combine information about the extents and relative intensities of perceived environmental risks to freshwater ecosystems. The first step in developing the ERS was to identify and map potential risk elements. Based on available data, we selected current agriculture and urban land cover types (polygons), roads (lines) and the locations of villages (points). Each risk element was assigned an intensity value and an influence distance. The intensity value is a measure of relative intensity on a 
Table 2 Intensity and influence distances assigned to different risk elements used to create an environmental risk surface

\begin{tabular}{llcc}
\hline $\begin{array}{l}\text { Risk } \\
\text { element }\end{array}$ & Class & Intensity & $\begin{array}{c}\text { Influence } \\
\text { distance }\end{array}$ \\
\hline $\begin{array}{l}\text { Agricultural } \\
\text { land cover }\end{array}$ & Any agriculture & 50 & 0 \\
$\begin{array}{l}\text { Urban land } \\
\text { cover }\end{array}$ & $\begin{array}{l}\text { High density } \\
\quad\left(50-75 \text { person } \mathrm{km}^{-2}\right)\end{array}$ & 100 & 10000 \\
& Medium density & 75 & 7000 \\
& $\quad(16-50)$ & & \\
Roads & Low density $(\leq 15)$ & 65 & 5000 \\
& Track & 10 & 5 \\
& Dirt road & 20 & 15 \\
& 2-lane highway & 50 & 60 \\
Villages & 4-lane highway & 50 & 200 \\
& Small $(\leq 2500$ persons $)$ & 45 & 3000 \\
& Large $(>2500$ persons $)$ & 55 & 3000 \\
\hline
\end{tabular}

0-100 scale with 100 being the strongest. Influence distance represents the 'maximum distance over which the feature has a negative impact on biodiversity' (Schill \& Raber, 2008). The assignment of intensity and distance values was a logical process informed by the literature and our judgment (Table 2). In particular, we drew on observations made by Allan (2004) about the relative influences of agriculture versus urban land uses on freshwater biological integrity and assumed that the influence distance of human communities was positively correlated with human population size or density (Table 2). The Protected Areas Tools for ArcMap 9.2 (v. 2.0) were used to attribute each risk element with their intensity and distance values. Each risk element was buffered by its distance of influence, and within this buffer, a linear decay function was used to simulate the decline of intensity away from the actual location of the risk type. Linear decay was used because of a lack of an a priori reason to assume nonlinear dissipation of risk. This process yielded a raster layer for each risk factor. These were summed to yield a cumulative ERS (Fig. 3, left). The ERS values of all upstream pixels were summed in a downstream direction (using the weighted flow accumulation tool in ArcMap) and divided by total number of upstream pixels to calculate a 'relative upstream risk intensity' value for each pixel (Fig. 3). The relative upstream risk values for all pixels in a river reach were averaged and associated with the local catchment for that reach for use in the Marxan total cost calculation.
Marxan can be parameterized to fix or exclude planning units into the final solution through the use of status codes. We excluded all local catchments in the Belize River watershed upstream of an area of extensive hydropower development and also excluded catchments where no fishes were predicted to occur. Finally, to increase the probability that our final portfolio would overlap with existing protected areas, we parameterized Marxan to place catchments with $>50 \%$ overlap with protected areas in the initial seed reserve network at the beginning of the Marxan run. This led to a greater probability of inclusion of these catchments in the final solution.

The data layers described above (catchments, boundary file, SDMs, ERS) were used to determine a portfolio of focal areas in two Marxan runs (Fig. 2). The first run was used to define the focal areas for migratory species only. This allowed us to define reserves in need of downstream migration corridors to the sea. In the second run, we fixed the migratory species focal areas into the final solution and generated the final portfolio of focal areas that encompassed $15 \%$ of the ranges of non-migratory species. Each Marxan run consisted of 200 iterations. We used a boundary length modifier (a coefficient that controls the strength of the boundary length cost in the solution) of 0.0001 . This modifier was selected using the technique recommended by Game \& Grantham (2008; p. 23).

After our portfolio of focal areas was generated, we defined critical management zones and catchment management zones for each focal area (Fig. 2). The migratory species we modelled require unimpeded connectivity between the river and the sea to complete their life cycles (McDowall \& Taylor, 2000). For this reason, the downstream migration corridors that connect upland habitats to the sea were defined as a critical management zone for migratory species focal areas.

Riparian buffers effectively protect habitat quality in downstream river reaches (Naiman, Decamps \& McClain, 2005) and thus were defined as a critical management zone in streams above all focal areas. It is difficult to derive rules of thumb for suitable buffer extent given the virtual absence of research on this topic in small tropical rivers, but several studies support the idea that longer buffer lengths correlate positively to increased biotic integrity downstream (Barton, Taylor \& Biette, 1985; Parkyn et al., 2003). In 


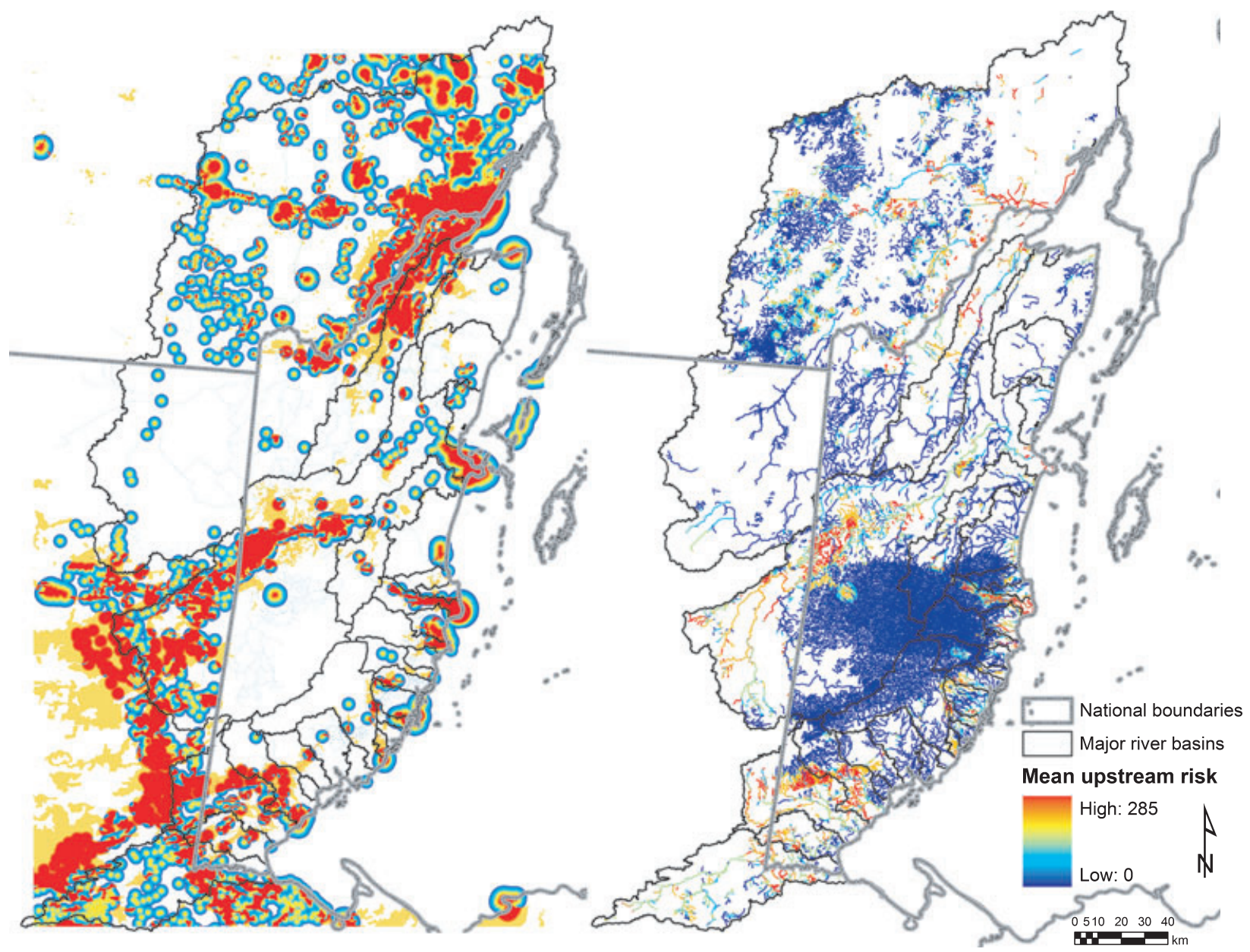

Fig. 3 Environmental risk surface (ERS) generated from agriculture and urban polygons, road lines and village points (left). This ERS was used as the weight grid in a weighted flow accumulation process to accumulate the intensity values in a downstream direction. The weighted flow accumulation was then divided by raw flow accumulation to give a measure of mean upstream risk intensity (right).

an extensive study of the influences of riparian vegetation cover on stream thermal regimes in New Zealand, Rutherford et al. (1997) found that 1-5 km buffers were suitable to maintain low temperatures in small (first-order to third-order) streams with low thermal inertia, while $10-20 \mathrm{~km}$ of forested buffer was necessary to maintain the natural thermal regime in fifth-order rivers. For the purposes of this study, we adopted an intermediate scenario and delineated all riparian habitats within a $5-\mathrm{km}$ zone upstream of all focal areas as critical management zones (which translates to $>5$ river $\mathrm{km}$ in a sinuous stream).

Catchment management zones were delineated as the entire watershed upstream of the most downstream focal area or critical management zone in a drainage basin.

(C) 2010 Blackwell Publishing Ltd, Freshwater Biology, 56, 71-88

\section{Results}

\section{Species distribution models}

The SDMs for all 63 species had AUCs that were significantly higher $(P<0.0001)$ than the distribution of AUCs from 100 null models, indicating that predictions performed significantly better than random and were valid for our planning exercise. Predicted range sizes relative to the total stream distance in the study area (31 257 linear km calculated from 1:50000 scale maps) ranged from 376 to $28642 \mathrm{~km}$ [Cichlasoma bocourti (Vaillant \& Pellegrin, 1902) and Heterandria bimaculata (Heckel, 1848) respectively], with a mean predicted occupancy of $9801 \mathrm{~km}$ (31\% of available habitat). Based on occurrence data, the assemblage occupied about half of the available 
elevational range from zero to 600 masl, with the majority of species limited to elevations below 200 masl (Appendix S1). Migratory species, with the exception of the opossum pipefish [Microphis brachyurus (Bleeker, 1853)], were distributed well into mountain areas where many protected areas are located. In contrast, most top predators inhabited the lower and estuarine reaches of watersheds. The narrow endemics - which comprised 12 of the 14 cichlids and eight of the 11 poeciliids in our dataset - were often limited to the northern or southern part of the area with ranges extending outside of the study boundaries. The spatial distributions of species from the different target groups in this analysis led to the selection of a final reserve network that spanned from north to south across biogeographic barriers, and across important environmental gradients like elevation.

\section{Reserve network}

The central reserve units of the system proposed by Abell et al. (2007) are freshwater focal areas, which are complemented by critical management zones and catchment management zones. The Marxan solution for migratory species focal areas defined a reserve network that successfully met our goal of $15 \%$ representation for all migratory species. The migratory species reserves were aggregated on the fringe of the Maya Mountains, in three large consolidated focal areas in the southern, central and northern coastal plain, and several smaller focal areas in the northern interior (Fig. 4). The combined migratory species focal areas occupied $1579 \mathrm{~km}^{2}$, or $3.5 \%$ of the study area.

The final Marxan solution with all species included was more than three times larger than the migratory species network. The final solution included an expanded band of catchments on the fringe of the Maya Mountains, larger consolidated focal areas in the coastal plain and northwest portion of the study area, and numerous small focal areas in the deep north (Fig. 4). In particular, more focal areas were identified in the two northernmost watersheds, where migratory species are scarce. However, many of these northern focal areas occurred in first-order catchments draining karst hills, which are probably dry for part of each year. The final network successfully met our $15 \%$ representation goal for 58 of the 63 species included as conservation features in our analysis and occupied $4935 \mathrm{~km}^{2}$ or $10.8 \%$ of the study area. Of the five species that did not receive $15 \%$ representation, three [C. bocourti, Thorichthys aureus (Günther, 1862) and Vieja godmanni (Günther, 1862)] were narrowly distributed endemics with ranges limited to the southernmost three basins, and two were catfishes [Ictalurus furcatus (Valenciennes, 1840), Sciades assimilis (Günther, 1864)] with habitats constrained largely to mainstem rivers. Of these, the only fish with $<12 \%$ representation $(8 \%)$ was $T$. aureus. This suggests that southern and main river habitats were slightly underrepresented in our final reserve solution.

The feasibility that the focal area portfolio will be implemented on the ground will be strongly influenced by its correspondence with existing protected areas. Managed or unmanaged but intact protected areas occupy $14667 \mathrm{~km}^{2}$ or c. $32 \%$ of the study area. These terrestrial reserves are concentrated in the rugged terrain of the Maya Mountains in the northwestern part of the study area, with a few also scattered across the coastal plains. Approximately $51 \%\left(2529 \mathrm{~km}^{2}\right)$ of focal areas occurred within existing protected areas (Fig. 5). The majority of focal areas lying outside of protected areas were in the northern half of the study area in the coastal plains where protected areas are less frequent (particularly in Mexico).

Critical management zones were defined for each focal area (Fig. 6). Migration corridors connecting migratory species focal areas to the sea were identified and mapped. There were 1256 linear $\mathrm{km}$ of migration corridors between migratory species focal areas and the coast $-4 \%$ of river $\mathrm{km}$ in the study area. Assuming a buffer width of $100 \mathrm{~m}$ on either side of the river along these corridors added $242 \mathrm{~km}^{2}$ of land $(0.5 \%$ of study area) to the portfolio. Inclusion of the same $200 \mathrm{~m}$ buffer in riparian corridors on streams $5 \mathrm{~km}$ upstream of each focal area added 3671 linear $\mathrm{km}$ of riparian corridors and $722 \mathrm{~km}^{2}(1.5 \%$ of study area) to the final reserve network. In several cases, riparian corridors connected nearby focal areas to one another creating 'meta-reserves' in the northern part of the study area (Fig. 6). Combined, the addition of critical management zones to the final reserve network expanded the reserve network by $964 \mathrm{~km}^{2}-\mathrm{a}$ $20 \%$ increase over the initial focal area network.

Catchment management zones, where integrated watershed management efforts are to be targeted, were defined from the lower extent of any given focal area or associated critical management zone, whichever

(C) 2010 Blackwell Publishing Ltd, Freshwater Biology, 56, 71-88 
Fig. 4 Freshwater focal areas defined using two runs of Marxan. The first run defined focal areas for migratory species (dark grey areas), which demand a special class of critical management zone. The second run (light grey areas) was constrained by the migratory species focal areas to select focal areas to protect the remainder of the species used as features in the exercise.

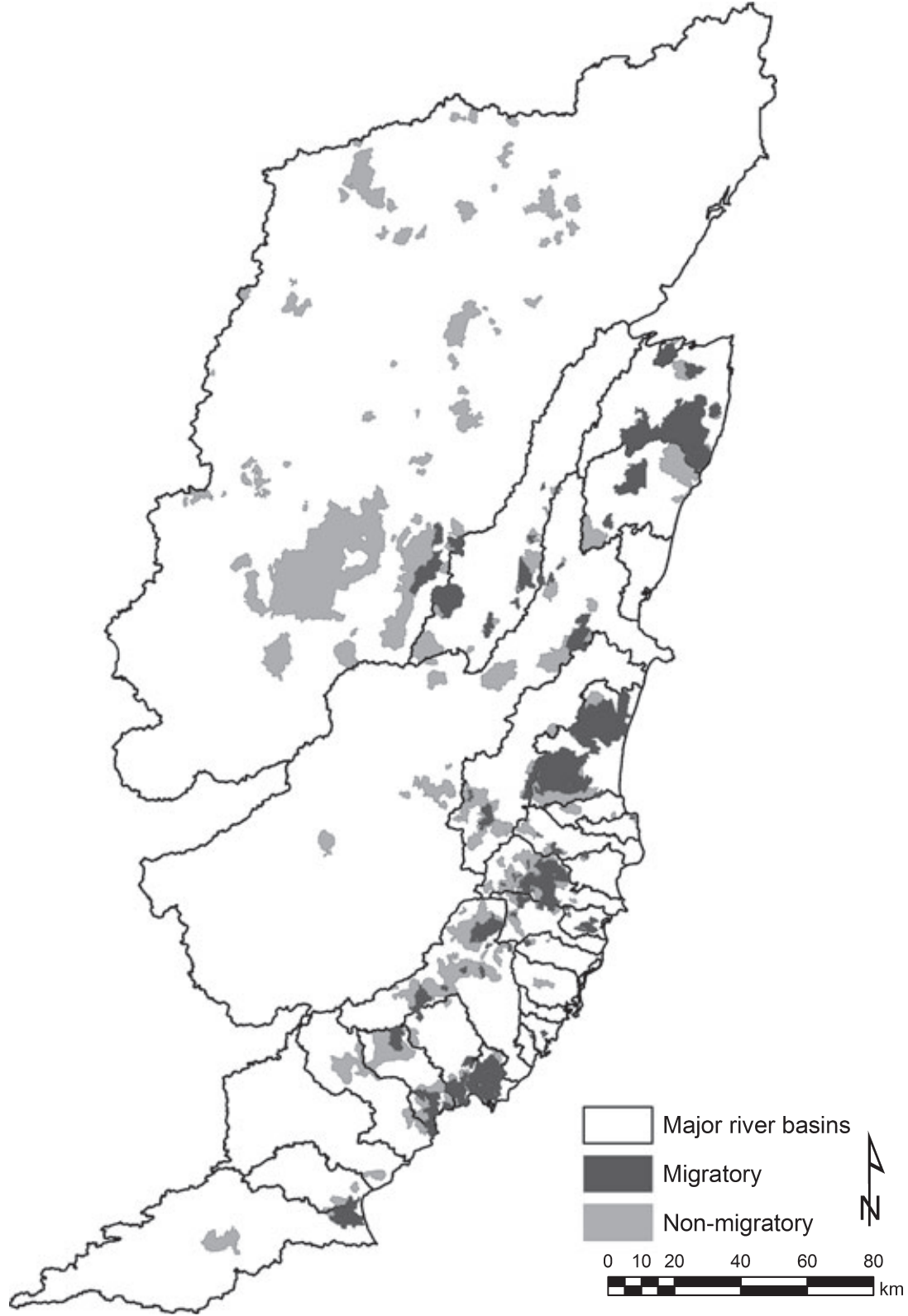

was more downstream (Fig. 6). Catchment management zones occupied $88 \%$ of the study area (40 $139 \mathrm{~km}^{2}$ ), in large part because migratory corridors stretched all the way to the river mouth in 13 of the 16 major drainage basins, thus incorporating entire basins in this management category (Fig. 6).

\section{Discussion}

Given the high degree of imperilment of freshwater species and ecosystems worldwide (Jenkins, 2003; Revenga \& Kura, 2003) and the importance of protected areas as general strategy for conservation (Groom, Meffe \& Carroll, 2006), protected area networks can and should be an important strategy to protect representative freshwater biodiversity (Crivelli, 2002; Saunders et al., 2002; Abell et al., 2007). Freshwater protected areas must not only incorporate important biodiversity features where they occur, but also consider physical directionality, connectivity and the transfer of stressors through a river network (Lake, 1980; Saunders et al., 2002). Various authors have proposed and demonstrated ways that these characteristics of freshwater ecosystems can be incorporated 


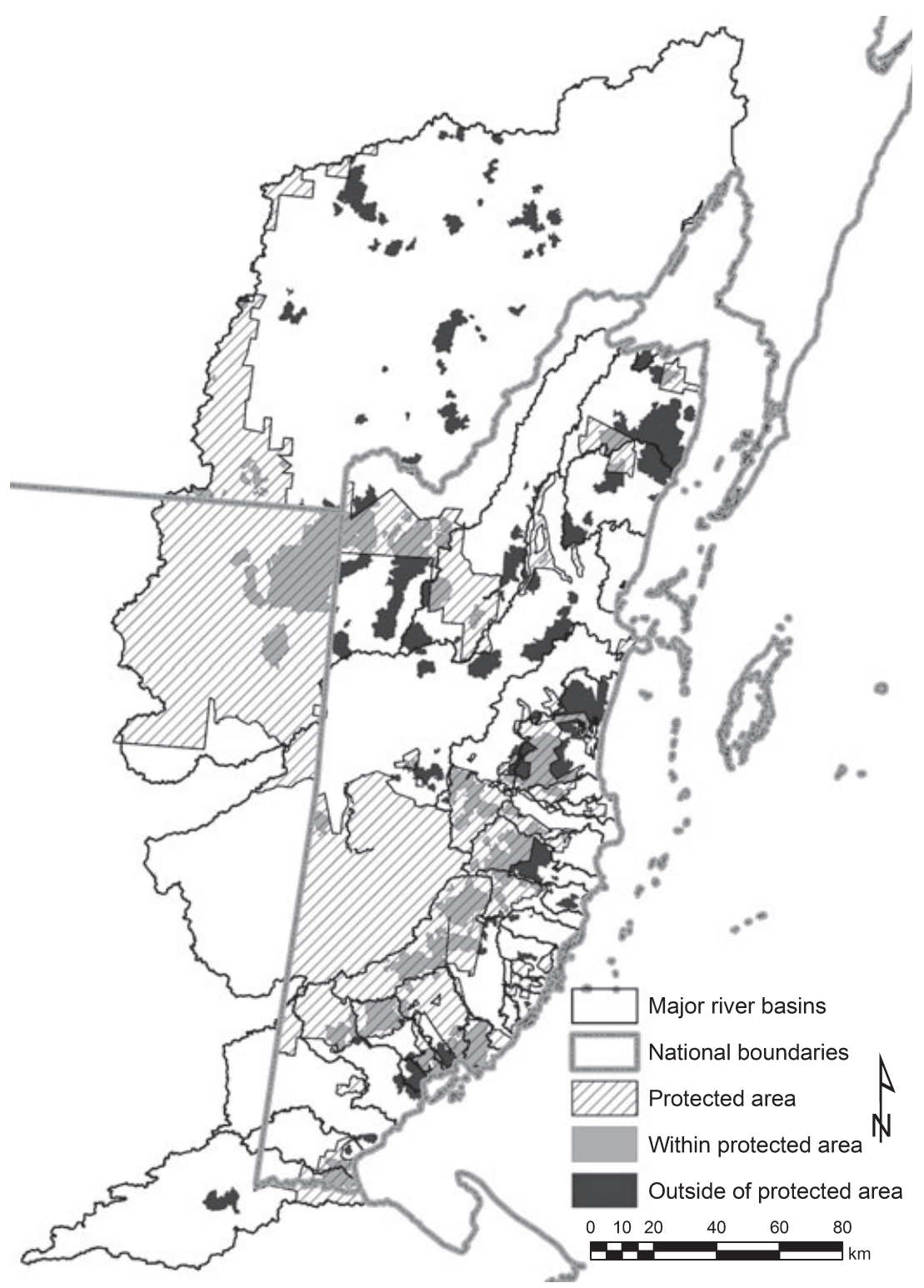

Fig. 5 The focal reserve network overlaid by managed and intact protected areas. Approximately, $51 \%$ of the selected focal areas were located within protected areas (light grey areas vs. dark grey areas which are outside of PAs). into protected area network design (Moyle \& Yoshiyama, 1994; Filipe et al., 2004; Linke et al., 2007; Thieme et al., 2007; Moilanen et al., 2008), and there has been recent call for yet more focus on this topic (Abell et al., 2007). In this article, we have added another case study to the small but growing list of papers that address connectivity in freshwater reserve design.

\section{An imperfect but useful representation of reality}

Data limitation is especially severe in tropical developing countries (Abell et al., 2008), which have extensive freshwater ecosystems and globally high levels of fish diversity and endemism (Amarasinghe \& Welcomme, 2002; Abell et al., 2008; Leveque et al., 2008). Thus, approaches are needed that maximise the utility of data types that are commonly available, like museum collection records and geospatial data. Internet-based data clearinghouses (e.g. the Global Biodiversity Information Facility; http://www.gbif. org) serve millions of georeferenced collection localities for fishes and other organisms to the public for easy manipulation in GIS. Here, we demonstrated how commonly available sources of data could be used to create SDMs that add biogeographic realism to the planning process.

(C) 2010 Blackwell Publishing Ltd, Freshwater Biology, 56, 71-88 
Fig. 6 The final portfolio including critical management zones (two classes) and catchment management zones.

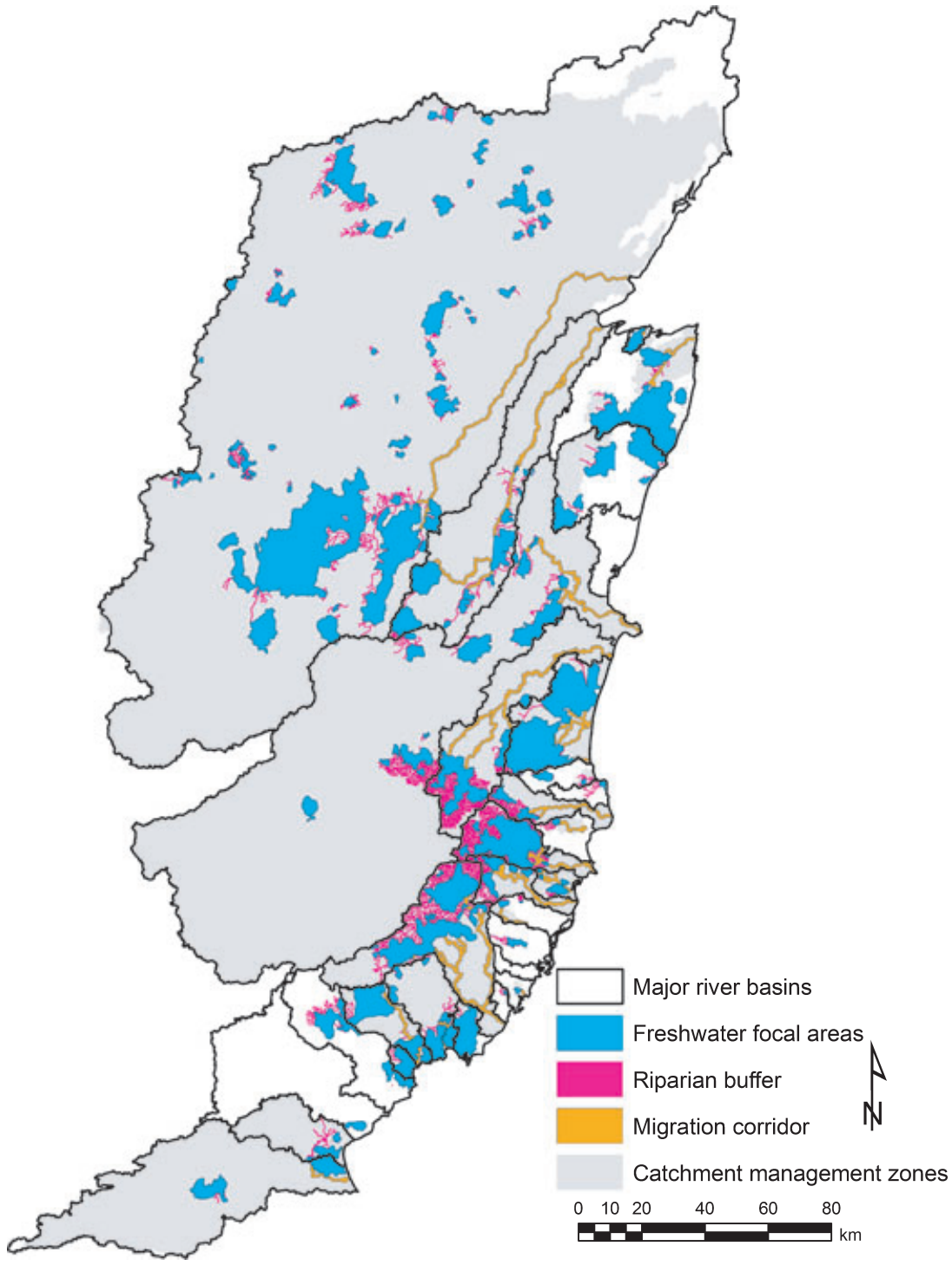

SDMs yield generalised estimates of the relationships between incomplete data about a species' niche and the often-biased locality data where the species has been recorded (Guisan \& Zimmermann, 2000). Bias in locality data can be caused by non-random site selection (near roads or other access points), spatially autocorrelated sites sampled in a restricted portion of a species' range, inaccurate georeferencing of sites, or mixing localities sampled using different gears of levels of effort (Phillips et al., 2006; Hernandez et al., 2008). These biases will often be present in data sets assembled in developing countries from ad hoc surveys, grey literature and museum records. It is necessary to identify and mitigate these issues to the greatest extent possible and to interpret models conservatively when these problems cannot be avoided. In our study, 129 of 303 sampling localities data were from studies with randomized site selection, conferring some degree of protection against bias. However, future effort to improve the accuracy of our range maps may be warranted through application of bias correction techniques (Dudík, Schapire \& Phillips, 2005). Nonetheless, the predicted ranges of species in our study closely approximated our knowledge of their distributional limits in the field, giving us confidence in their utility for this planning exercise. Further, we accounted for bias in model validation by restricting the randomly drawn points for our null models to the 303 fish collection localities used to construct SDMs. This corrects for the influence of bias 


\section{P. C. Esselman and J. D. Allan}

on the judgment of model validity by ensuring that SDMs and null models are equally biased and thus directly comparable (Raes \& ter Steege, 2007). Despite potential problems, SDMs frequently perform well when validated internally and against independent data (Elith et al., 2006). For this reason, SDMs have increasingly been used in reserve design (Cocks \& Baird, 1989; Araujo \& Williams, 2000; Williams \& Araujo, 2000; Polasky \& Solow, 2001; Filipe et al., 2004), including increased application to reserve design in freshwater contexts (Filipe et al., 2004; Linke et al., 2007; Moilanen et al., 2008; V. Hermoso, Linke, Prenda \& Possingham, 2010).

\section{Systematic conservation planning in a riverine context}

Reserve design is often aided by software that identifies networks that efficiently protect representative biodiversity (Sarkar et al., 2006). We chose a widely applied and available software package, Marxan, for our study, which was originally designed for use in marine and terrestrial settings (Ball et al., 2009). Translation of Marxan and other software (e.g. ZONATION; Moilanen et al., 2008) to flowing-water settings poses some challenges. Among these are the representation of longitudinal and lateral connectivity and the downstream influence of human activities. We addressed these problems in three ways. First, we represented connectivity between catchment planning units to respect major drainage divides, thus forcing Marxan to only define focal areas within and not across these major barriers to species movement. Second, we represented relative magnitudes of environmental risk in the landscape in a way that considered the potential downstream transfer of risk from human activities and the influence that basin size might have on downstream accumulation of risk. Third, we post-processed the focal area network defined by Marxan to define secondary management zones designed to maintain high-quality habitats, facilitate migration and abate threats to species in freshwater focal areas.

Several other recent studies have addressed connectivity in freshwater systematic conservation planning. Linke et al. (2007) and Moilanen et al. (2008) incorporated connectivity more explicitly than we did by drawing on spatial databases with network topology. Such databases link each local catchment with their upstream watersheds and the next downstream catchment, allowing for accurate representation of connectivity at the sub-basin level (Linke et al., 2007; Moilanen et al., 2008). Without the benefit of network topology, we were only able to constrain the representation of connectivity between planning units at the basin level, potentially resulting in Marxan solutions that crossed sub-basin divides. However, our ERS accurately represented connectivity at the subbasin level, and thus may have enforced similar solutions to those that would have resulted from having an explicitly defined network topology.

Our relative upstream risk index, when incorporated into Marxan, served as the unit cost term in the total cost function and guided network solutions away from catchments with greater risk from agriculture, roads and human settlements in their watersheds. Because higher risk areas tended to be found in the same stream networks (Fig. 3, right), the ERS probably guided Marxan away from higher risk sub-basins and towards sub-basins with lower costs among longitudinally connected planning units. The ideal representation of connectivity would include accurate representation of network topology (as in Linke et al., 2007; Moilanen et al., 2008) and a realistic representation of how risk is propagated in dendritic networks.

Our representation of downstream transfer of combined anthropogenic risk offers benefits over other examples found in the published literature on freshwater reserve planning. Contrasting studies have used presence or absence of human activity in subbasins as a measure of ecosystem intactness (Thieme et al., 2007), categorical estimates of river integrity established through expert workshops (Nel et al., 2007), consideration of single threats (e.g. water availability; Roux et al. (2008)), or no consideration of the locations of anthropogenic activities (Filipe et al., 2004). In an approach more similar to that used here, Linke et al. (2007) considered threats integrated over the upstream catchment. That study combined direct measures of catchment condition (e.g. nutrient and sediment budgets) and indirect measures (e.g. proportions of different land uses and road density) into composite stressor gradients that were incorporated into a heuristic reserve design algorithm. While this scheme allows for relative ranking of planning units in an ordinated multi-dimensional 'risk space', it does not provide a strong basis for estimating numeric risk magnitudes. In contrast, the approach of Schill \&

(C) 2010 Blackwell Publishing Ltd, Freshwater Biology, 56, 71-88 
Raber (2008) presented here directly represents assumed risk magnitudes in a directionally appropriate way and thus has good potential to be used in freshwater conservation planning.

Our study presents the first practical application of the design framework of Abell et al. (2007) and the first published assessment of freshwater protected areas in Mesoamerica. Application of the framework of Abell et al. (2007) added little work to the reserve design process, and if implemented on the ground, will provide critical protections to species and habitats, without which species persistence would be far more tenuous. When compared to reserve management in a terrestrial setting, implementing Abell et al.'s (2007) three-part network probably creates added complexity to reserve management. A management presence will still be required within freshwater focal areas just like in terrestrial reserves, but additional management effort will be needed (i) to successfully protect riparian corridors and longitudinal connectivity within them and (ii) to coordinate large-scale landscape planning with public and private entities that control land use practices in catchment management zones. While an exploration of specific management issues is beyond the scope of this article, a critical evaluation of the logistical, policy and management dimensions of such extended reserve networks is warranted. More generally, we echo others who call for further refinement and critical exploration of approaches to design efficient reserve networks for place-based conservation of freshwater biodiversity.

\section{Acknowledgments}

This work was funded by the Inter-American Biodiversity Information Network on a grant from the World Bank Development Grants Facility, the Belize Protected Areas Conservation Trust, the Rackham Graduate School at the University of Michigan (UM), the UM School of Natural Resources and Environment and the UM Office of the Vice President for Research. This work would not have been possible without facilitation by the Belize Foundation for Research and Environmental Education, El Colegio de la Frontera Sur, The Guatemala Program of the Nature Conservancy, the Belize Fisheries Department (Beverly Wade, George Myvett, and Rigoberto Quintana), and the Belize Forest Department (Wilbur Sabido, Raul
Chun). We thank Simon Linke, David Strayer and two anonymous reviewers for helpful comments. Special thanks are also due to Rebecca Esselman, Vincent Abreu, Juan Jacobo Schmitter-Soto, Matt Cushing, Shannon Brines, Steve Schill, Emil Cherrington, Sandor Ricketts, Rennick Jackson, David Buck, Sonny Gabutt, Michael Issa, Miles, Lars and Irin Lish. All field data collected as part of this research were conducted under protocol \#09339 issued by the University of Michigan University Committee on the Use and Care of Animals.

\section{References}

Abell R., Allan J.D. \& Lehner B. (2007) Unlocking the potential of protected areas for freshwaters. Biological Conservation, 134, 48-63.

Abell R., Thieme M., Revenga C. et al. (2008) Freshwater ecoregions of the world: a new map of biogeographic units for freshwater biodiversity conservation. BioScience, 58, 403-414.

Allan J.D. (2004) Landscapes and riverscapes: the influence of land use on stream ecosystems. Annual Review of Ecology Evolution and Systematics, 35, 257-284.

Amarasinghe U.S. \& Welcomme R.L. (2002) An analysis of fish species richness in natural lakes. Environmental Biology of Fishes, 65, 327-339.

Araujo M.B. \& Williams P.H. (2000) Selecting areas for species persistence using occurrence data. Biological Conservation, 96, 331-345.

Ardron J.A., Possingham H.P. \& Klein C.J. (2008) Marxan Good Practices Handbook. Pacific Marine Analysis and Research Association, Vancouver, BC.

Ball I.R., Possingham H.P. \& Watts M. (2009) Marxan and relatives: software for spatial conservation prioritisation. In: Spatial Conservation Prioritisation: Quantitative Methods and Computational Tools. (Eds A. Moilanen, K.A. Wilson \& H.P. Possingham), pp. 185-195. Oxford University Press, Oxford, UK.

Barton D.R., Taylor W.D. \& Biette R.M. (1985) Dimensions of riparian buffer strips required to maintain trout habitat in southern Ontario streams. North American Journal of Fisheries Management, 5, 364-378.

Benstead J.P., March J.G., Pringle C.M. \& Scatena F.N. (1999) Effects of a low-head dam and water abstraction on migratory tropical stream biota. Ecological Applications, 9, 656-668.

Bussing W.A. (1976) Geographic distribution of the San Juan ichthyofauna of Central America with remarks on its origin and ecology. In: Investigations of the Ichthyofauna of Nicaraguan Lakes. (Ed T.B. Thorson), 
pp. 157-175. University of Nebraska, Lincoln, Nebraska.

Cocks K.D. \& Baird I.A. (1989) Using mathematical programming to address the multiple reserve selection problem: an example from the Eyre Peninsula, south Australia. Biological Conservation, 49, 113-130.

Crivelli A.J. (2002) The role of protected areas in freshwater fish conservation. In: Conservation of Freshwater Fishes: Options for the Future. (Eds M.J. CollaresPereira, I.G. Cowx \& M.M. Coelho), pp. 373-388. Fishing News Books, Oxford, UK.

Cruz G.A. (1987) Reproductive biology and feeding habits of cuyamel, Joturus pichardi and tepemechín, Agonostomus monticola (Pisces, Mugilidae) from Rio Platano, Mosquitia, Honduras. Bulletin of Marine Science, 40, 63-72.

Cruz G.A. (1989) Sexually mature Joturus picardi (Pisces, Mugilidae) captured in Laguna de Brus and in the disemboguement of Rio Platano, Honduras. Revista de Biología Tropical, 37, 107-108.

Dudík M., Schapire R.E. \& Phillips S.J. (2005) Correcting sample selection bias in maximum entropy density estimation. In: Advances in Neural Information Processing Systems 18. (Eds Y. Weiss, B. Schölkopf \& J. Platt), pp. 323-330. MIT Press, Boston, MA.

Elith J., Graham C.H., Anderson R.P. et al. (2006) Novel methods improve prediction of species' distributions from occurrence data. Ecography, 29, 129-151.

Esselman P.C. \& Boles E. (2001) Status and future needs of limnological research in Belize. In: Limnology in Developing Countries Volume 3. (eds R.G. Wetzel \& B. Gopal), pp. 35-68. International Association for Limnology, New Delhi, India.

Esselman P.C., Freeman M.C. \& Pringle C.M. (2006) Fishassemblage variation between geologically defined regions and across a longitudinal gradient in the Monkey River Basin, Belize. Journal of the North American Benthological Society, 25, 142-156.

Fielding A.H. \& Bell J.F. (1997) A review of methods for the assessment of prediction errors in conservation presence/absence models. Environmental Conservation, 24, 38-49.

Filipe A.F., Marques T.A., Seabra S., Tiago P., Ribeiro F., Da Costa L.M., Cowx I.G. \& Collares-Pereira M.J. (2004) Selection of priority areas for fish conservation in Guadiana River basin, Iberian Peninsula. Conservation Biology, 18, 189-200.

Frissell C.A., Liss W.J., Warren C.E. \& Hurley M.D. (1986) A hierarchical framework for stream habitat classification: viewing streams in a watershed context. Environmental Management, 10, 199-214.

Game E.T. \& Grantham H.S. (2008) Marxan User Manual for Marxan Version 1.8.10. The University of Queens- land Pacific Marine Analysis and Research Association, Vancouver British Columbia, Canada, St. Lucia, Queensland, Australia.

Gilbert C.R. \& Kelso D.P. (1971) Fishes of the Tortuguero area, Caribbean, Costa Rica. Bulletin of the Florida State Museum of Biological Sciences, 16, 1-54.

Graham C.H., Ferrier S., Huettman F., Moritz C. \& Peterson A.T. (2004) New developments in museum-based informatics and applications in biodiversity analysis. Trends in Ecology and Evolution, 19, 497-503.

Greenfield D.W. \& Thomerson J.E. (1997) Fishes of the Continental Waters of Belize. University of Florida Press, Gainesville, FL.

Groom M.J., Meffe G.K. \& Carroll C.R. (2006) Principles of Conservation Biology, 3rd edn. Sinauer Associates Inc., Sunderland, MA.

Guisan A. \& Zimmermann N.E. (2000) Predictive habitat distribution models in ecology. Ecological Modelling, 135, 147-186.

Halpern B.S., Borer E.T., Seabloom E.W. \& Shurin J.B. (2005) Predator effects on herbivore and plant stability. Ecology Letters, 8, 189-194.

Hartshorn G., Nicolait L., Hartshorn L., Bevier G., Brightman R., Cal J., Cawich A., Weyer D.H. \& Wright A. (1984) Belize Country Environmental Profile: A Field Study. USAID, Belize City, Belize.

Hermoso V., Linke S., Prenda J. \& Possingham H.P. (2010) Addressing longitudinal connectivity in freshwater systematic conservation planning. Freshwater Biology, 56, 57-70.

Hernandez P.A., Graham C.H., Master L.L. \& Albert D.L. (2006) The effect of sample size and species characteristics on performance of different species distribution modeling methods. Ecography, 29, 773785.

Hernandez P.A., Franke I., Herzog S.K. et al. (2008) Predicting species distributions in poorly studied landscapes. Biodiversity Conservation, 17, 13531366.

Higgins J.V., Bryer M.T., Khoury M.L. \& Fitzhugh T.W. (2005) A freshwater classification approach for biodiversity conservation planning. Conservation Biology, 19, 432-445.

Hynes H.B.N. (1975) The stream and its valley. Verhandlungen Internationale Vereinigung für theoretische und angewandte Limnologie, 19, 1-15.

Jenkins M. (2003) Prospects for biodiversity. Science, 302, 1175-1177.

Lake P.S. (1980) Conservation. In: An Ecological Basis for Water Resource Management. (Ed. W.D. Williams), pp. 163-173. Australian National University Press, Canberra, Australia.

(C) 2010 Blackwell Publishing Ltd, Freshwater Biology, 56, 71-88 
Lee M.D., Stednick J.D. \& Gilbert D.M. (1995) Belize Environmental Water Quality Monitoring: Final Report. USAID-NARMAP Project to Government of Belize, Belmopan, Belize.

Leveque C., Oberdorff T., Paugy D., Stiassny M.L.J. \& Tedesco P.A. (2008) Global diversity of fish (Pisces) in freshwater. Hydrobiologia, 595, 545-567.

Linke S., Pressey R.L., Bailey R.C. \& Norris R.H. (2007) Management options for river conservation planning: condition and conservation re-visited. Freshwater Biology, 52, 918-938.

Margules C.R. \& Pressey R.L. (2000) Systematic conservation planning. Nature, 405, 243-253.

McDowall R.M. \& Taylor M.J. (2000) Environmental indicators of habitat quality in a migratory freshwater fish fauna. Environmental Management, 25, 357-374.

Meyer J.L., Strayer D.L., Wallace J.B., Eggert S.L., Helfman G.S. \& Leonard N.E. (2007) The contribution of headwater streams to biodiversity in river networks. Journal of the American Water Resources Association, 43, 86-103.

Miller R.R. (1966) Geographical distribution of Central American freshwater fishes. Copeia, 1966, 773-802.

Moilanen A., Leathwick J. \& Elith J. (2008) A method for spatial freshwater conservation prioritization. Freshwater Biology, 53, 577-592.

Moyle P.B. \& Randall P.J. (1998) Evaluating the biotic integrity of watersheds in the Sierra Nevada, California. Conservation Biology, 12, 1318-1326.

Moyle P.B. \& Yoshiyama R.M. (1994) Protection of aquatic biodiversity in California: a five-tiered approach. Fisheries, 19, 6-18.

Naiman R.J., Decamps H. \& McClain M.E. (2005) Riparia: Ecology, Conservation, and Management of Streamside Communities. Elsevier Academic Press, Burlington, MA.

Nel J.L., Roux D.J., Maree G., Kleynhans C.J., Moolman J., Reyers B., Rouget M. \& Cowling R.M. (2007) Rivers in peril inside and outside protected areas: a systematic approach to conservation assessment of river ecosystems. Diversity and Distributions, 13, 341-352.

Parkyn S.M., Davies-Colley R.J., Halliday N.J., Costley K.J. \& Croker G.F. (2003) Planted riparian buffer zones in New Zealand: do they live up to expectations? Restoration Ecology, 11, 436-447.

Phillips S.J., Dudík M. \& Schapire R.E. (2004) A maximum entropy approach to species distribution modeling. In: Proceedings of the 21st International Conference on Machine Learning. pp. 655-662. Banff, Canada. ACM Press, New York.

Phillips S.J., Anderson R.P. \& Schapire R.E. (2006) Maximum entropy modeling of species geographic distributions. Ecological Modelling, 190, 231-259.
Poff N.L. (1997) Landscape filters and species traits: towards mechanistic understanding and prediction in stream ecology. Journal of the North American Benthological Society, 16, 391-409.

Polasky S. \& Solow A.R. (2001) The value of information in reserve site selection. Biodiversity and Conservation, 10, 1051-1058.

Possingham H.P., Ball I.R. \& Andelman S. (2000) Mathematical methods for identifying representative reserve networks. In: Quantitative Methods for Conservation Biology. (Eds S. Ferson \& M. Burgman), pp. 291-305. Springer, New York.

Possingham H.P., Wilson K.A., Andelman S.J. \& Vynne C.H. (2006) Protected areas: goals, limitations, and design. In: Principles of Conservation Biology, 3rd edn. (Eds M.J. Groom, G.K. Meffe \& C.R. Carroll), pp. 509551. Sinauer Associates, Inc., Sunderland, MA.

Pringle C.M. (1997) Exploring how disturbance is transmitted upstream: going against the flow. Journal of the North American Benthological Society, 16, 425438.

Pringle C.M., Scatena F.N., Paaby-Hansen P. \& NunezFerrera M. (2000) River conservation in Latin America and the Caribbean. In: Global Perspectives on River Conservation: Science, Policy, and Practice. (Eds P.J. Boon, B.R. Davies \& G.E. Petts), pp. 41-77. John Wiley and Sons Ltd., New York.

Raes N. \& ter Steege H. (2007) A null-model for significance testing of presence-only species distribution models. Ecography, 30, 727-736.

Revenga C. \& Kura Y. (2003) Status and trends of biodiversity of inland water ecosystems. In: Technical Series No. 11. Secretary of the Convention on Biological Diversity, Montreal, Canada.

Rivers-Moore N.A., Goodman P.S. \& Nel J.L. (2010) Scalebased freshwater conservation planning: towards protecting freshwater biodiversity in KwaZulu-Natal, South Africa. Freshwater Biology, 56, 125-141.

Rondinini C., Wilson K.A., Boitani L., Grantham H. \& Possingham H.P. (2006) Tradeoffs of different types of species occurrence data for use in systematic conservation planning. Ecology Letters, 9, 1136-1145.

Roux D.J., Nel J.L., Ashton P.J. et al. (2008) Designing protected areas to conserve riverine biodiversity: lessons from a hypothetical redesign of the Kruger National Park. Biological Conservation, 141, 100117.

Rutherford J.C., Davies-Colley R.J., Quinn J.M., Stroud M.J. \& Cooper A.B. (1997) Stream Shade: Towards a Restoration Strategy. Department of Conservation Wellington, New Zealand.

Sarkar S., Pressey R.L., Faith D.P. et al. (2006) Biodiversity conservation planning tools: present status and 
challenges for the future. Annual Review of Environment and Resources, 31, 123-159.

Saunders D.L., Meeuwig J.J. \& Vincent A.C.J. (2002) Freshwater protected areas: strategies for conservation. Conservation Biology, 16, 30-41.

Schill S. \& Raber G. (2008) Protected Area Tools (PAT) for ArcGIS 9.2 Version 2: User Manual and Tutorial. The Nature Conservancy, Arlington, VA.

Schmitter-Soto J.J. (1998) Catalogo de los peces continentales de Quintana Roo. El Colegio de la Frontera Sur, San Cristobal de las Casas, Mexico.

Schmitter-Soto J.J. \& Gamboa-Pérez H.C. (1996) Composición y distribución de peces continentales en el sur de Quintana Roo, Peninsula de Yucatan, Mexico. Revista de Biología Tropical, 44, 199-212.

Skelton P.H., Cambray J.A., Lombard A. \& Benn G.A. (1995) Patterns of distribution and conservation status of freshwater fishes in South Africa. South African Journal of Zoology, 30, 71-81.

Stoms D.M., Davis F.W., Andelman S. et al. (2005) Integrated coastal reserve planning: making the landsea connection. Frontiers in Ecology and the Environment, 3, 429-436.

Thieme M., Lehner B., Abell R., Hamilton S.K., Kellndorfer J., Powell G. \& Riveros J.C. (2007) Freshwater conservation planning in data-poor areas: an example from a remote Amazonian basin (Madre de Dios River, Peru and Bolivia). Biological Conservation, 135, 484-501.

Tonn W.M., Magnuson J.J., Rask M. \& Toivonen J. (1990) Intercontinental comparison of small-lake fish assemblages: the balance between local and regional processes. American Naturalist, 136, 345-375.

Townsend C.R. (1996) Concepts in river ecology: pattern and process in the catchment hierarchy. Archive für Hydrobiologie, (Suppl. 113), 3-21.

Vannote R.L., Minshall G.W., Cummins K.W., Sedell J.R. \& Cushing C.E. (1980) River continuum concept. Canadian Journal of Fisheries and Aquatic Sciences, 37, 130-137.
Ward J.V. \& Wiens J.A. (2001) Ecotones of river ecosystems: role and typology, spatiotemporal dynamics, and river regulation. Ecohydrology and Hydrobiology, 1, 2536.

Williams P.H. \& Araujo M.B. (2000) Using probability of persistence to identify important areas for biodiversity conservation. Proceedings of the Royal Society of London Series B-Biological Sciences, 267, 1959-1966.

Wilson E.M. (1980) Physical geography of the Yucatan Peninsula. In: Yucatan: A World Apart. (Eds E.H. Moseley \& E.D. Terry), pp. 5-40. University of Alabama Press, Alabama.

Winemiller K.O. \& Leslie M.A. (1992) Fish assemblages across a complex, tropical fresh-water marine ecotone. Environmental Biology of Fishes, 34, 29-50.

Wishart M.J., Davies B.R., Boon P.J. \& Pringle C.M. (2000) Global disparties in river conservation: 'First world' values and 'third world' realities. In: Global Perspectives on River Conservation: Science, Policy, and Practice. (Eds P.J. Boon, B.R. Davies \& G.E. Petts), pp. 353-369. John Wiley and Sons Ltd., New York.

\section{Supporting Information}

Additional Supporting Information may be found in the online version of this article:

Appendix S1. Fish species list and pertinent environmental and biological data.

As a service to our authors and readers, this journal provides supporting information supplied by the authors. Such materials are peer-reviewed and may be re-organised for online delivery, but are not copyedited or typeset. Technical support issues arising from supporting information (other than missing files) should be addressed to the authors.

(Manuscript accepted 9 February 2010) 